\title{
Severe Generalized Edema Associated with Phenelzine
}

\author{
William Bobo M.D. \\ National Capital Cosortium Military Psychiatry Residency - National Naval Medical Center, Walter Reed \\ Army Medical Center
}

Cheryl A. Hemme M.D.

Department of Psych/Neurology, University of Missouri, Columbia School of Medicine

\section{Follow this and additional works at: https://jdc.jefferson.edu/jeffjpsychiatry \\ Part of the Psychiatry Commons \\ Let us know how access to this document benefits you}

\author{
Recommended Citation \\ Bobo, William M.D. and Hemme, Cheryl A. M.D. (2001) "Severe Generalized Edema Associated with \\ Phenelzine," Jefferson Journal of Psychiatry. Vol. 16 : Iss. 1 , Article 7. \\ DOI: https://doi.org/10.29046/JJP.016.1.006 \\ Available at: https://jdc.jefferson.edu/jeffjpsychiatry/vol16/iss1/7
}

This Article is brought to you for free and open access by the Jefferson Digital Commons. The Jefferson Digital Commons is a service of Thomas Jefferson University's Center for Teaching and Learning (CTL). The Commons is a showcase for Jefferson books and journals, peer-reviewed scholarly publications, unique historical collections from the University archives, and teaching tools. The Jefferson Digital Commons allows researchers and interested readers anywhere in the world to learn about and keep up to date with Jefferson scholarship. This article has been accepted for inclusion in Jefferson Journal of Psychiatry by an authorized administrator of the Jefferson Digital Commons. For more information, please contact: JeffersonDigitalCommons@jefferson.edu. 


\title{
Severe Generalized Edema Associated with Phenelzine
}

\author{
William Bobo, M.D. ${ }^{1}$ and Cheryl A. Hemme, M.D. ${ }^{2}$
}

\begin{abstract}
Rabkin, et al. describes a 4\% incidence of phenelzine-induced edema, which appears to be due to increased capillary permeability $(1,2)$. This adverse effect is not further characterized in the literature and is not readily mentioned as one of the many drug effects that could result in severe physical morbidity. We present the case of a depressed patient who developed a generalized edema severe enough to deserve an extensive medical workup. Once the drug was tapered, the edema and its associated symptoms rapidly resolved.
\end{abstract}

\section{CASE REPORT}

MW is a 51 year old female with a psychiatric history of recurrent severe major depression and a past medical history of only mild asthma. She had failed fluoxetine and fluvoxamine after initial positive response; however, her depressed mood would return in settings of severe psychosocial stress. While on a maximum dose of fluvoxamine, she expressed suicidal intent. MW was thus admitted for inpatient care, where she responded to phenelzine.

After hospitalization, MW remained stable on phenelzine; however, she presented after four months without medication follow-up complaining of progressive swelling in all extremities. She also complained of worsening shortness of breath, severely decreased exercise tolerance, a 50 pound weight gain and three-pillow orthopnea without chest pain. Clinical exam was unremarkable except for the aforementioned edema. Complete blood count, erythrocyte sedimentation rate, serum albumin, BUN/creatinine, TSH and urinalysis were all normal. A hydrocholrothiazide trial failed to bring her edema under control.

Two months later, MW was referred to psychiatry for continued management of her mood disorder and possible phenelzine discontinuation. Her progressive "heart failure-like" symptomatology had become so severe that she was almost entirely dependent on others to provide basic self-care; thus, a slow taper from phenelzine was started. After being off of phenelzine for two weeks, MW noted decreased

\footnotetext{
${ }^{1}$ William V. Bobo, M.D., LT, MC, USNR, Residency: National Capital Cosortium Military Psychiatry Residency (National Naval Medical Center, Walter Reed Army Med Ctr).

${ }^{2}$ Cheryl Hemme, M.D., Director, General Psych Residency Training, Dept of Psych/Neurology-Univ. of MO-Columbia School of Medicine.
} 
swelling in all extremities with a return of full range of motion. Her orthopnea and exercise tolerance had improved dramatically. Mental status examination that time revealed near resolution of her mood symptoms. At her next follow up examination 4 weeks later, she reported continued symptom remission, with further improvements noted in her subjective report of mood state and energy level as a result of continued correction of phenelzine-induced weight changes. She was followed clinically off of medication.

The patient's experience suggests that the edema associated with phenelzine can be quite handicapping if allowed to progress. Our clinical experience with phenelzine has been very favorable, with our "typical" case of drug-induced edema consisting of lower extremity swelling without significant sequelae. This experience is likely shared by other clinicians who make use of this medication; however, we should be forewarned that some patients may develop severe, complicated edema, presenting health risks and physical morbidities that outweigh therapeutic benefit.

\section{REFERENCES}

1. Rabkin J, Quitkin F, Harrison W, et al: Adverse reactions to monoamine oxidase inhibitors. Part I. A comparative study. J Clin Psychopharmacel 1984; 4: 270-278.

2. Rabkin J, Quitkin F, McGrath P, et al: Adverse reactions to monoamine oxidase inhibitors. Part II. Treatment correlates and clinical management. J Clin Psychopharmacol 1985; 5: $2-9$. 